\section{Immunotherapy with $\mathrm{BiTE}^{\circledR}$ Antibodies: Lessons Learned from Blinatumomab}

\section{G. Zugmaier ${ }^{1}$}

1 Executive Medical Director Global Development, AMGEN Research (Munich) GmbH, Munich

T cell-engaging bispecific antibodies can transiently link with otherwise inactive cytotoxic $T$ cells in patients' tumor cells and induce redirected potent lysis of tumor cells. One example for this is blinatumomab (AMG 103), a CD19/-CD3-bispecific BiTE ${ }^{\circledR}$ antibody used to treat acute lymphocytic leukemia (ALL) and non-Hodgkin's lymphoma (NHL), which is in an advanced stage of clinical development. Two other BiTE ${ }^{\circledR}$ antibodies, AMG 211/MEDI-565 (CEA/CD3-specific) and AMG 110 (EpCAM/CD3-specific), are in the early stages of clinical development to treat solid tumors. Blinatumomab and all other BiTE ${ }^{\circledR}$ antibodies have been shown to activate T cells in a highly conditional manner that was strictly dependent on the presence of target cells, effect the serial lysis of target cells by $\mathrm{T}$ cells, induce $\mathrm{T}$ cell proliferation, and act at sub-nanomolar concentrations. The mode of action of BiTE ${ }^{\circledR}$ will be described in detail and compared to other treatment modalities. Phase 2 studies investigating monotherapy using blinatumomab in patients with minimal residual $(n=20)$ or relapsed $\operatorname{ALL}(\mathrm{n}=36)$ have shown complete response rates in the range of $50-80 \%$ at a dose level of 15 micrograms/square meter/ day. In a Phase 1 study $(n=76)$, the BiTE $^{\circledR}$ antibody blinatumomab has also shown high response rates in relapsed or refractory NHL patients with follicular mantle cell lymphoma or diffuse large B cell lymphoma at a dose level of 60 micrograms/square meter/day $(n=28)$. An overview of the clinical program and insights into the immunopharmacology, safety profile, and clinical activity of blinatumomab will be provided.
Conflict of Interest: Prof. Zugmaier is employed by AMGEN Research (Munich) GmbH

\author{
References \\ 1 Klinger M et al. Blood 2012; 119: 6226 \\ 2 Cioffi $M$ et al. Clin Canc Res 2012; 18: 465 \\ 3 Topp M et al. J Clin Oncol 2011; 29: 2493 \\ 4 Nagorsen D, Baeuerle PA. Exp Cell Res 2011; 317: 1255 \\ 5 Lutterbuese R et al. Proc Natl Acad Sci USA 2010; 107: 12605-12610 \\ 6 Baeuerle PA, Reinhardt C. Cancer Res 2009; 69: 4941 - 4944 \\ 7 Haas C et al. Immunobiol 2009; 214: 441 - 453 \\ 8 Bargou R et al. Science 2008; 321: 974-977 \\ 9 Brischwein Ket al. J Immunother 2007; 8: 798-807 \\ 10 Hoffmann P et al. Intl J Cancer 2005; 115: 98-104 \\ 11 Offner $S$ et al. Mol Immunol 2005; 43: 763-771 \\ 12 Dreier T et al. Intl J Cancer 2002; 100: 690-697
}

\section{Bibliography}

DOI http://dx.doi.org/10.1055/s-0032-1324899

Arzneimittelforschung 2012; 62, Suppl. 1: S3-\$3

(c) Georg Thieme Verlag KG Stuttgart · New York .

ISSN 0004-4172 